Article

\title{
Complexity and Volume: An Inquiry into Factors that Drive Principals' Work
}

\section{Katina Pollock $^{1, *}$, Fei Wang ${ }^{2}$ and David Cameron Hauseman ${ }^{3}$}

1 Faculty of Education, Western University, 1137 Western Rd., London, ON N6G 1G7, Canada

2 Faculty of Education, Department of Educational Studies, The University of British Columbia, 2125 Main Mall, Vancouver, BC V6T 1Z4, Canada; E-Mail: fei.wang@ubc.ca

3 Department of Leadership, Higher and Adult Education, Ontario Institute for Studies in Education at the University of Toronto, 252 Bloor Street West, Toronto, ON M5S 1V6, Canada;

E-Mail: chausema@uwo.ca

* Author to whom correspondence should be addressed; E-Mail: kpolloc7@uwo.ca; Tel.: +1-(519)-661-2111 (ext. 82855); Fax: +1-(519)-661-3833.

Academic Editors: Kenneth Leithwood and Jingping Sun

Received: 30 March 2015 / Accepted: 18 May 2015 / Published: 2 June 2015

\begin{abstract}
Background: The work of contemporary school principals is intensifying in terms of its complexity and volume. Many factors moderate and drive such work intensification. This study aims to understand what and how factors interact to complicate principals' work. Methods: Focus groups and an online survey were used for data collection. Three focus group sessions with eight principals were conducted to help develop and refine the online survey. The survey covers 12 key areas in principals' work and was distributed among the members of Ontario Principals' Council. Descriptive statistics, correlation and factor analysis were conducted on survey results. Results: The study shows that there are many key areas that moderate principals' work, such as administrative duties and responsibilities, jurisdictional policies, external influences, partnerships, and challenges and possibilities. School principals are experiencing increased expectations at work in terms of the number of tasks they are expected to undertake, the duration of time they are required to complete those tasks, and the many challenges they face at their work. Conclusions: Principals' choice of leadership approaches and practices is subject to factors that exist within and beyond schools. Such factors moderate the way that principals carry out their work and limit their choices in exercising their professional autonomy.
\end{abstract}


Keywords: principals' work; school leadership; moderating factors; instructional leadership; budgeting; partnerships; policies; technology; changing student demographics; labour issues

\section{Introduction}

"Increased workload is the biggest change in the work of principals."

- Canadian Association for Principals [1] (p. 22).

The past three decades have seen a growing interest in principals' work [2-6]. Specifically, there has been a growing emphasis on the work of principals in relation to improving student achievement [7-10]. In an effort to learn more about what principals can do to improve student achievement, the field of educational leadership has considered principals' behaviours and practices in relation to: recruiting and motivating quality teachers [11,12], articulating a school vision [13,14], effective allocation of resources [10,15], and supporting instructional learning [2,16-19].

Investigating leadership effects on student performance has a long history within the school effectiveness and improvement movement [20]. Over the past few decades, scholars have attempted to find both direct [21] and indirect [22-25] effects of school leadership on student outcomes. Most current empirical studies are premised on the notion that the influence of school leadership on student outcomes is indirect; principals "directly operate on school organisational and instructional conditions, which in turn influence student achievements" [7] (p. 374). Hendriks and Scheerens' [7] matching of core leadership behaviors to educational effectiveness factors is one way to consider how principals indirectly affect student outcomes.

While the majority of articles in this special issue address some component of Leithwood, Patten, and Jantzi's [26] four paths used by leaders to indirectly improve student learning, this article takes a different approach by considering what variables influence schools leaders' work. Specifically, we consider the variables in Leithwood, Patten and Jantzi's [26] "organizational path," and how some of these variables influence principals' work (and therefore indirectly influence their ability to impact student achievement). Briefly, the organizational path consists of variables that can constitute principals' working conditions such as structures, culture, policies and standard operation procedures [26]. The variables examined in this study affect what principals do along the paths, which can be considered antecedents to what leaders do. These variables can fall into the following categories: administrative duties and responsibilities, jurisdictional policies, external influences and partnerships, and challenges and possibilities. Our inquiry is in a preliminary stage, and we are therefore not able to make causal linkages using the data presented here; rather, the data is meant to raise questions and considerations for further inquiry into the phenomenon of school leadership effects and the role played by principals' work as a moderator of principals' functions and behaviours.

This study takes a broad approach to understanding what contemporary principals do. Among other things, it acknowledges the wide-ranging, diverse, and complex nature of principals' work. Most importantly, it adopts the concept of "work" to explore principals' worlds. "Work," for this article, is understood as labour or effort expended to achieve a particular set of goals [27]. This study includes 
employment-related paid and unpaid work [28]. The labour included in this study may be expended both within and outside position-related roles enacted by principals, and includes efforts that are both paid and unpaid. It is difficult in this day and age to erect clear boundaries around work efforts, just as it is to define organizational boundaries [29]. Work can take place on and off the school site, and it can occur before or after the official opening and closing of the school day. Work also comprises particular experiential components such as physical, mental, and emotional aspects [30,31]; this is certainly the case for principals who are deeply engaged in emotional labour [32] in addition to their cognitive and observable activities. In line with studies that look at work engagement [33,34], this study employs a lens that acknowledges the behavioural, cognitive, and emotional elements of work.

\section{Factors that Influence Principals' Work}

There are a number of moderating factors that can influence a principal's workload. Some of these factors can be categorised as follows: instructional leadership, administrative/management responsibilities, partnerships, policies, and external influences.

\subsection{Instructional Leadership}

Not surprisingly, instructional leadership had a variety of meanings [35]. In Ontario, the Education Act does not make any specific reference to instructional leadership being part of the principals' official role [36]. However, as part of Ontario's Leadership Strategy (OLS), the Ontario Leadership Framework (OLF) does suggest that education leaders, such as curriculum leaders, principals, and supervisory officers, are to

...embed direct involvement in instruction in their daily work through teamwork with all staff focused on improved school and classroom practices...[and] help to create inclusive and instructionally effective learning environments that increase the likelihood that all students will be successful learners" [37] (p. 7).

For the purposes of this article, we view instructional leadership as leadership of curriculum where school principals are: "developing, supervising, evaluating, and are accountable for instructional programs; hiring, supervising, evaluating, and providing professional development opportunities for school staff; supporting student advancement; and evaluating student performance and progress" [38] (n.p.).

\subsection{Administrative/Management Responsibilities}

Like running any organization that has a physical site, principals are also responsible for a number of administrative or managerial responsibilities. For this article, we focus on four specific responsibilities: budgeting, personnel, building maintenance, and occupational, health and safety compliance.

\subsubsection{Budgeting}

Schools have always had budgets and leaders of schools have always had some kind of interaction with these budgets, from merely knowing what the fiscal amount is and where the funds are going to site-based management with full discretion on how to spend the annual budget. However, it appears 
that with the onset of reform efforts and school improvement initiatives, "budgeting" has become more complex than previously experienced. In 2013, the Organization for Economic Co-operation and Development (OECD) Teaching and Learning International Survey (TALIS) report ranked "inadequate school budget and resources" as the top barrier to principal effectiveness; in Alberta, Canada it was ranked second [39]. In Ontario, a recent study indicated that nearly one third of the 70 principals interviewed required additional professional learning to manage the school's budget or deal with other financial aspects of the position [38].

\subsubsection{Personnel}

Managing personnel should be a component of instructional leadership functions, where principals develop people or redesign the organization [40]. While this most definitely can be the case, there is a pragmatic element to working with people that requires principals to be knowledgeable about labour contracts and possess skills such as conflict resolution, the ability to supervise multiple employee groups, and to address grievances [41].

\subsubsection{Building Maintenance}

Maintaining a school site is not an easy task, and it is rarely discussed outside of the school finance literature. Principals working in older schools are faced with difficult decisions about allocation of resources, must self-educate on what needs to be prioritized, and must oversee any renovations and/or repairs [42]. However, it is not just older buildings that require principals' time and attention; new school development projects can be just as taxing on a school principal's time. New school buildings require an effective maintenance plan that includes meeting warranty deadlines and constant revisiting as the building ages [43].

\subsubsection{Occupational Health and Safety}

Principals play a pivotal role in creating a healthy school community. Principals can do this by limiting occupational health and safety hazards and by promoting a positive and inclusive climate $[1,44]$. However, their work intensification can have a significant impact on their own occupational health and safety. Recognizing principals' occupational health and safety is imperative in creating a culture of wellness in schools. Studies show that principals who are exposed to long work hours are more likely to have unhealthy life styles (e.g., in regards to weight gain, smoking, and/or alcohol consumption) [45-47]. Such unhealthy lifestyle habits can eventually undermine the overall health of school communities, and even affect teaching and learning in schools.

\subsection{Partnerships}

A "partnership," for this article, is understood as a relationship with an outside organization or group (as opposed to relationships with individual parents or families). Many advocate that partnerships can be a way to support student achievement [48], and can be considered a part of instructional leadership. Even though partnerships can indirectly support student achievement, we have separated this category from instructional leadership, as it does not facilitate principals' direct 
involvement in curriculum instruction in their daily work. Schools are being encouraged to engage in outside partnerships for all sorts of reasons: to generate revenue, such as by renting out building space after school hours [49]; to foster closer connections to services that the school cannot effectively provide, such as supplemental educational services [50]; or as a way of engaging ethnic, racial, and religious communities with the school and with student learning [51,52]. Effective partnerships require trusting relationships, a central purpose, and leadership, to name but a few components [53]. For many principals, engaging in partnerships at the school level requires engaging in partnership-building and maintenance tasks that can at times take them away from direct school functions.

\subsection{Policies}

Reform movements and accountability initiatives over the past 10 years or so have utilized policies as tools to initiate and support educational change. However, the way we understand "policy," and its implications is complex, and "it would appear that everyone has an individually constructed concept of policy" [54] (p. 35). However, for this article, we understand "policy" as a way to change practice through official, formal legislation, mandates, government initiatives, and board regulations. Policies act to regulate, constrain, and/or monitor actions and outcomes. In Ontario, principals' work is not only influenced by the Ontario Education Act 1990, but according to the Ontario College of Teachers, principals are also expected to have a working knowledge of at least 17 different provincial and federal legislations [55]. In addition to the formal legislation, principals are subject to provincial ministry initiatives and strategies, such as: the Aboriginal Education Strategy; the Equity and Inclusive Education Strategy; the Parents in Partnership: Parent Engagement Policy; the First Nations, Metis, and Inuit (FNMI) Policy Framework; Growing Success: Assessment, Evaluation, and Reporting in Ontario Schools; the Ontario curriculum; and the Ontario Leadership Strategy.

What we know from recent studies in Canada and Ontario is that policies are playing a more significant role in principals' work than in the past. We know generally that many school principals feel that their role is constrained by the number of initiatives imposed on a school [56-58]. Not only do principals in Ontario feel constrained by formal policy initiatives, but multiple policy initiatives within short time periods have also influenced how they do their work [59]. The Organization for Economic Co-operation and Development (OECD) Teaching and Learning International Survey (TALIS) report ranked "government regulation and policy" as third on its list of barriers to principal effectiveness [39].

\subsection{Other External Influences}

In addition to the aforementioned partnerships with organizations and groups outside of schools, current Canadian literature suggests other external influences can have an impact on principals' work. Some examples of external influences captured here include: technology, changing student demographics, district school board initiatives, and labour issues.

\subsubsection{Technology}

Advances in information and communication technology have made principals' work more complicated [38]. From a positive perspective, information and communication technology can 
provide principals with additional channels through which they can reach students, parents, and the wider community [60-62]. However, the downside to these technologies is that they require principals to expend significant time and energy learning how to use them. Some principals have had to engage in steep learning curves to operate devices such as smart phones and utilize different forms of social media [63,64]. Work-life boundaries can become blurred as some principals are expected to complete tasks or respond to emails in an unrealistic timeframe. Approximately, $49 \%$ of principals reported that technological changes the way people communicate. This is challenging because principals feel they are always "on call" [38]. The amount of emailing has increased to a level that principals indicated there were "too many memos and emails from the district which increase[d]workload and distract[ed] principals" [64]. Lastly, an unforeseen consequence of advances in information and communication technology is the increased prevalence of cyberbullying [1]. Principals have reported having to spend enormous amounts of time managing "discipline-related problems emerging from tech-facilitated bullying and gossip" [1] (p. 41). Cyberbullying has become such an issue that the Canadian Association of Principals concluded: "the fallout from social media use in the school community places a significant burden on administrator's time" [1] (p. 41).

\subsubsection{Changing Student Demographics}

Changing student demographics influence principals' work in three ways. First, the student population influences the size, location, type of school, number of special classrooms, and make-up of the student population and the educational services required to support individualized needs, special programs, and discipline. Declining student enrolment also influences principals' workload. Similar to most developed countries, Canada is experiencing a demographic shift towards an aging population [39]. A declining student population means there are currently fewer students enrolled in formal schooling. In addition to following the regulations for possible school closure that require extensive consultations with many stakeholders, principals indicated that declining student enrolment could also mean impending layoffs. Staff members are often extremely concerned about job security in these situations, and employment uncertainty can be a barrier to building and sustaining a healthy and positive school environment [38].

Lastly, changing student demographics also includes principals' growing awareness of increased student diversity. Student diversity can include differences based on race, ethnicity, religion, sexual orientation, socio-economic status, cultural heritage, or ability, for example [65]. When 70 Ontario principals were asked how they understood student diversity, they tended to respond in terms of race, ethnicity, religion, socio-economic status, student mental health, and different learning styles/abilities [38]. This is not surprising, as Canada is a country of immigrants, and has one of the highest per capita immigration rates in the world [66]. Currently, slightly more than $20 \%$ of Canada's population was born outside of the country, and a number of different ethnic groups call Canada home [67]. As the student population becomes more diverse, principals spend more time fostering relationships with external cultural, religious, and ethnic organizations [68] and local community organizations [69]. 


\subsubsection{District School Board Demands}

Schools do not exist in a vacuum; they are part of a larger system that includes school boards/districts, and larger political jurisdictions. Since the development of schooling systems, school principals have often been thought of as "middle managers" - the "overseer[s] of buses, boilers and books" [70] (p. 4) -within a hierarchy steeped in bureaucratic processes. From this perspective, principals carry out a number of functions, such as buffering teachers from "outside distractions" [7]. Pressures brought on by external demands can impede principals from focusing on the instructional aspect of their work. Schools have always been accountable in one way or another [71-75] and there are multiple accountability approaches. The current dominant accountability approach in Canada is performance-based accountability (PBA) [76]. Different approaches to accountability have generated multiple initiatives that directly affect the function of principals and their work. Principals in the Canadian Association of Principals study report that "accountability mandates from the provincial governments and school districts translated to 'reams of paperwork' and 'countless hours filling out reports" [1] (p. 37). Administrators believe that these accountability measures "force us to report results in a manner that takes away from kids" [1] (p. 37).

\subsubsection{Labour Issues}

Throughout the history of education in Canada, labour relations in the educational sector have been relatively stable, with the occasional periodic dispute. Over the years, provincial government turnovers, legislative changes, and new educational policies have had and continue to have a dramatic impact on work relationships between teachers and school principals. In Ontario and British Columbia, principals are not part of teachers' union but rather are considered part of 'management'. The removal of Ontario principals from the teachers protective labour association has changed the nature of labour relations so that the way principals interact with other educators and staff has also changed $[38,77,78]$. Sixteen percent of Ontario Principals recently identified contracts "that prevent staff from being flexible and willing to support students" as having a negative effect on their workload [64] (p. 20). The Canadian Association of Principals has also documented that principals in British Columbia "devote far more of their time to warding off and adjudicating labour-management disputes than is the case in other provinces. This deprives them of time that could be used to focus on improving instruction" [1] (p. 83).

\section{Methodology}

Data gathered for this study comes from Ontario, Canada. In Canada, the federal role in schooling is limited; public education falls under provincial jurisdiction [79]. In Ontario, 72 district school boards are spread across the following four types of publicly funded school systems:

- English;

- French;

- English-Catholic; and

- French-Catholic. 
Data gathered for this study comes primarily from members of a jurisdictional association representing English-language principals and vice-principals in the province. No Catholic or Frenchspeaking district school boards were included in this study. A mixed method research design was employed to gather data for this study [80]. Data collection methods included focus groups with practicing principals and a large-scale online survey. Each of these methods is described in detail below.

\subsection{Focus Groups}

The focus groups were conducted with principals primarily to gain feedback while developing the online survey. A total of three focus group sessions were conducted with between eight principals as part of the survey development process. A diverse sample of participants representing different career stages, genders and locations (rural, urban, suburban) were involved in the focus group sessions. Each focus group session consisted of two distinct parts. During the first hour, participating principals were asked to discuss the nature of their work. In the second part of the focus group sessions principals piloted the survey questions, offering feedback on the survey's overall design, formatting of questions, and content.

\subsection{Online Survey}

The online survey was designed to best represent the broad range of tasks, responsibilities, behaviours, and practices expected of principals in contemporary times, and it was revised a number of times to achieve this goal. Much of the literature cited earlier, and recent changes to jurisdictional education policy (e.g., regulations surrounding equity and inclusion in schools and school-based hiring practices) were captured in the survey questions. After the initial draft of the online survey was reviewed by the study funder, the second stage of survey development involved piloting a revised version of the tool with current school principals during focus groups, which were described in detail above. The final stage of survey development involved incorporating valuable feedback offered by focus group participants into the tool. The final online survey contained 60 questions and asked principals about their work in the following 12 areas:

- how they spend their time;

- duties and responsibilities;

- accountability and external influences;

- challenges and possibilities;

- well-being and job satisfaction;

- work and life balance;

- supports;

- the Ontario Leadership Framework;

- professional development;

- school-level partnerships;

- personal information; and

- school details. 
In addition to collecting data on the 12 areas mentioned above, the survey offered principals the opportunity to qualify their responses by providing additional comments when answering certain questions, or/and when they had completed the survey. Only three open-ended survey questions received the number of responses necessary to conduct meaningful quantitative analysis. The analysis involves counts and percentages of the patterns and themes as identified from the comments. Those questions inquired about school-level partnerships with external programs or agencies (1240 unique responses), accountability (854 unique responses), and coping mechanisms (250 unique responses). The "Additional Comments" section at the end of the survey received 788 unique responses. Qualitative data has been woven throughout the article to reinforce findings.

Examples of the questions utilized to measure each of the 12 areas of principals' work explored in the survey can be found in Table 1. These are used to highlight antecedents and moderating factors influencing principals and their work.

Table 1. Examples of Survey Items.

\begin{tabular}{l}
\hline Area of Inquiry \\
How principals spend their time \\
Duties and responsibilities \\
Accountability and external influences \\
Challenges and possibilities
\end{tabular}

\section{Example of Survey Question}

On average, how many hours do you work per week?

Below are some school-based social programs, please check those that have an impact on your work as a principal.

Please rank in order the stakeholders you feel most to least accountable to:

To what extent does each of the following statements characterize you and your relationship with your school superintendent?

To what extent do you agree or disagree with the following statements about you and your work?

Well-being and job satisfaction

a) my school is a good place to work;

b) I have a choice in deciding what I do at work;

c) I never seem to have enough time to get my work done;

d) I can decide when to take a break during my working day;

e) I feel pressured to work long hours;

f) I can make my own decisions about how I do my work;

g) The pace of my work is too fast;

h) I know how to get my job done;

i) I have the appropriate resources to do my job; and

j) My job makes a difference in the school community

Work and life balance

Supports

The Ontario Leadership Framework

Professional development

School-level partnerships

Personal information

School details
Do you feel you have an appropriate balance between your work and your life outside of work?

How much support do you receive from the following organizations?

Does your current work as a principal reflect the direction of the Ontario Leadership Framework?

Within the past two years, please rank the top three skills you have needed to develop in order to navigate the changing educational agenda (increased parental involvement, economy focused education, new systems of accountability, etc.)?

Approximately how many community groups and/or community organizations (i.e., churches, charities, local businesses) are you currently involved in within your school community?

What is the highest level of formal education you have completed? What is the current school enrollment? 


\subsubsection{Online Survey Sample}

The sample consisted of members of the jurisdictional association representing principals and vice-principals in Ontario at the time the survey was online. The sample is made up of principals employed in the English-language school boards at the time the survey was online. The research team was provided with a list of e-mail addresses for all 2701 members of the jurisdictional principals' association, who, at the time of the survey, were designated as principals working in Ontario. Utilizing SurveyMonkey software, each of these principals was sent an individualized URL that led to the online survey. These links were active for 26 days. Despite having direct access to the respondents, a number of additional strategies were employed to encourage principals to share their opinions and make their voices heard using the survey. The research team sent weekly e-mail reminders to principals who had yet to complete the survey. Further, website updates and tweets were also employed to encourage participation. These strategies help explain why the survey was able to achieve such a high response rate (52.68\%). The response rate is based on 1423 completed surveys available for analysis after accounting for missing data and eliminating ineligible respondents.

\subsubsection{Characteristics of the Sample}

The sample of principals who participated in the online survey was diverse in some ways, and less diverse in others. For example, $62.8 \%$ of the principals who responded to the online survey self-identified as female, while the remaining $36.2 \%$ of participants self-identified as male. A total of $77.3 \%$ of principals worked in elementary school contexts, while $16.4 \%$ were secondary principals, and $2.9 \%$ were principals of both elementary and secondary schools. The average number of years of experience as a principal for the total sample is 7.6 years. Respondents' average school size was 493 students, and school sizes ranged from 25 to approximately 2200 students. When asked about the highest level of formal education they had completed, 54.3\% reported having a Master's degree in addition to their undergraduate degrees. This is compared to $41.6 \%$ of the sample who hold bachelor's degrees as their highest level of formal education. An additional $2.4 \%$ of principals in this sample indicated that they have earned a professional degree (i.e., LLB, JD), while only $1.3 \%$ have completed a doctorate or other terminal degree.

As mentioned earlier, the principals who participated in this study were less diverse in other areas. For instance, the vast majority of principals (91.4\%) self-identified as heterosexual. A total of $3.4 \%$ of principals who responded to the online survey self-identified as gay or lesbian, with smaller numbers of participants self-identifying as bisexual and transgendered (both under $1 \%$ of the sample). It is worth mentioning that an additional $2.7 \%$ of participating principals indicated that they would prefer to not disclose this information. Ethnicity is another area where the sample lacks diversity, with $92.5 \%$ of the entire sample self-identifying as Caucasian. A further $1.6 \%$ of the sample self-identified as black, with $1.3 \%$ self-identifying as South Asian. While these percentages are representative of the Ontario principal workforce, they do not represent the Ontario general population where approximately $25 \%$ are from visible minoritized groups (Statistics Canada, 2011), or Ontario's student population [81]. 


\subsection{Data Analysis}

The data analysis focuses on areas that influence principals' work, such as jurisdictional policies, administrative duties and responsibilities, external influences, partnerships, and challenges and possibilities. These variables speak more to the "organizational path" than the other pathways as identified in Leithwood, Anderson, Mascall and Strauss' 2010 book chapter [82]. The analysis of these organizational variables supplements, if not precedes, Leithwood and colleagues' study by looking into the antecedents and moderators that have significant impact on school principals' work. In the present study factor analysis was used to investigate variable relationships for the aforementioned complex areas (e.g., jurisdictional policies, administrative duties and responsibilities, external influences, partnerships, and challenges and possibilities). Such analysis is designed to identify similar patterns of responses in the multiple observed variables. The factor analysis also investigates concepts that are not easily measured directly by reducing a large number of variables into a few interpretable underlying and potent factors. Variables that significantly explain the overall variance of the factors are used in the multiple regression analysis, which is employed to understand, among the organizational variables, which ones have a significant impact on principals' work.

Principal components analysis with varimax rotation and Kaiser Normalization were conducted to obtain conceptually similar and significant clusters of issues on how principals spend their time, their responses to jurisdictional policies, external influences, and challenges and possibilities. These two procedures produce results designed to cluster individual variables into single factors. Eigenvalues are employed when making decisions about the number of factors that will be extracted as part of the factor analysis process. In this case, Eigenvalues, equal to or greater than 1.00 were extracted.

Additional descriptive statistics and correlation analysis were also conducted to supplement the factor analysis. The descriptive statistics were presented in percentages to provide a summary of a particular area in the data. Correlation analysis was used to explore relationships among variables that might have predictive abilities across factors.

\section{Results}

The changing work structure has a significant impact on principals as well as on their school performance. Principals are experiencing increased expectations at work both in terms of the number of tasks they are expected to undertake and the duration of time they are required to complete those tasks; they have many tasks to perform and less time to carry them out. The research findings report on factors that contribute to principals' work intensification, and how such factors influence principals' leadership practices. Each of the following four areas consisted of factors that moderate principals' work:

- administrative duties and responsibilities;

- jurisdictional policies;

- external influences and partnerships; and

- challenges and possibilities

Antecedents on principals' work for these four areas will be discussed in the remainder of this article. 


\subsection{Administrative Duties and Responsibilities}

Our research indicates that principals spend approximately $59 \mathrm{~h}$ per week at work, $14 \mathrm{~h}$ a week more than other Canadian occupational managers [83]. Most of the principals who responded to this survey indicated that they are hardworking by nature, but that workload demands are making the position increasingly challenging. For instance, in qualitative responses reported in the "Additional Comments" section, one principal mentioned, "I am not afraid of hard work or long hours because of my personal work ethic but I do feel resentful that I am chained to the job." Another principal stated, "I love my job. I love what I do. I just cannot do it."

As the volume of principals' work increases, their administrative duties and responsibilities are becoming more complicated as well. Fifteen variables related to principals' administrative duties and responsibilities utilized in the survey are listed in Table 2. ${ }^{1}$ Analysis of the 15 variables (orthogonal rotation) yielded four factors, ${ }^{2}$ accounting for $29.9 \%, 10.2 \%, 8.6 \%$, and $7.3 \%$ of the total variance respectively, a total of $55.9 \%$ of the total variance explained. The factor loadings are presented in Table 2. To enhance the interpretability of the factors, only variables with factor loads as follows were selected for inclusion in their respective factors: $>0.51$ (factor one), $>0.57$ (factor two), $>0.57$ (factor three), and $>0.82$ (factor four). The factors are named, respectively, administrative management, instructional leadership, interactions with students and parents, and professional development. These factors indicate that principals spend their time each week mostly on these four areas.

Table 2. How Principals Spend Their Time.

\begin{tabular}{ccccc}
\hline Variables & $\begin{array}{c}\text { Administrative } \\
\text { Management }\end{array}$ & $\begin{array}{c}\text { Instructional } \\
\text { Leadership }\end{array}$ & $\begin{array}{c}\text { Interaction with } \\
\text { Students \& Parents }\end{array}$ & $\begin{array}{c}\text { Professional } \\
\text { Development }\end{array}$ \\
\cline { 2 - 5 } & Factor 1 & Factor 2 & Factor 3 & Factor 4 \\
\hline Student discipline & -0.117 & -0.043 & $\mathbf{0 . 8 0 6}$ & 0.031 \\
Student-related activities & 0.103 & 0.189 & $\mathbf{0 . 5 9 9}$ & 0.182 \\
Student transportation & 0.207 & 0.186 & 0.441 & -0.089 \\
Working with parents & 0.355 & 0.217 & $\mathbf{0 . 5 7 4}$ & 0.087 \\
DSB office committees & $\mathbf{0 . 5 1 9}$ & -0.257 & 0.095 & 0.497 \\
Principals' PD & 0.002 & 0.191 & 0.108 & $\mathbf{0 . 8 2 2}$ \\
Curriculum \& instructional & 0.232 & $\mathbf{0 . 5 7 3}$ & -0.025 & 0.517 \\
leadership & & & & \\
Budget & $\mathbf{0 . 7 1 0}$ & 0.204 & 0.180 & 0.115 \\
Personnel & $\mathbf{0 . 6 8 6}$ & 0.019 & 0.150 & 0.117 \\
Internal school management & $\mathbf{0 . 6 1 0}$ & 0.092 & -0.088 & 0.089 \\
Walking hallways, playground, & 0.131 & $\mathbf{0 . 6 1 1}$ & 0.296 & -0.034 \\
lunchroom & & & & \\
Classroom walk-throughs & 0.139 & $\mathbf{0 . 8 1 9}$ & 0.150 & 0.174 \\
Building maintenance & $\mathbf{0 . 6 3 1}$ & 0.497 & 0.181 & 0.043 \\
Occupational health \& safety & $\mathbf{0 . 6 8 3}$ & 0.230 & 0.155 & -0.159 \\
\hline
\end{tabular}

1 Boldface shows loadings for each factor and underlines indicate cross loadings. This also applies to other tables on factor analysis results.

2 The item "community" has cross loadings on factor 1 and 2 and is deleted in order to enhance the quality of variables for final factor analysis. 
Specifically, with regard to administrative management, principals reported spending more time on budget (factor loading $=0.71$ ) and personnel (factor loading $=0.68$ ). Budget and personnel are more correlated to administrative management than occupational health and safety, building maintenance, internal school management, and district school board office committees. The analysis also brought attention to principals' occupational health and safety, which has a significant correlation to the administrative management factor with a loading of 0.66. Among the items of the second factor, classroom walk-throughs are highly correlated to instructional leadership (factor loading $=0.82$ ). On average, principals spend $12.7 \%$ of their day in classrooms. The analysis also revealed that principals spend a significant amount of time interacting with students and parents. Such interaction focuses particularly on student discipline (factor loading $=0.81$ ) on which principals spend an average of $7.6 \mathrm{~h}$ per week; $52.7 \%$ of principals confirm that is the amount of time they should spend on student discipline. Principals' professional development (PD) is another important factor in terms of how principals spend their time. In order to navigate the current educational climate, principals felt that it was important to develop their skills in the area of emotional intelligence, communication skills, and knowledge of teaching and learning. Seventy-four percent of school principals expressed their desire for more time and opportunities to engage in professional development. Based on principals' estimate, Table 3 presents an overview of how they spend their time on each of the activities at their work. In average, principals spent approximately $7.6 \mathrm{~h}$ per week on student discipline and $7.5 \mathrm{~h}$ per week on internal school management. These two activities take up a significant amount of principals' time among all their work activities.

Table 3. Time Spent on Each Activity.

\begin{tabular}{cc}
\hline Variables & Number of Hours Spent Per Week \\
\hline Student discipline & 7.6 \\
Student-related activities & 5.2 \\
Student transportation & 1.2 \\
Working with parents & 5.6 \\
DSB office committees & 5.4 \\
Principals' PD & 2 \\
Curriculum \& instructional leadership & 5 \\
Budget & 1.8 \\
Personnel & 5.6 \\
Internal school management & 7.5 \\
Walking hallways, playground, lunchroom & 5.8 \\
Classroom walk-throughs & 3.1 \\
Building maintenance & 1.8 \\
Occupational health \& safety & 1.5 \\
\hline
\end{tabular}

\subsection{Policies}

Recent jurisdictional policy changes are another factor having an impact on principals' work. Recent policy changes that have influenced principals' work, listed in descending order, with the most impactful at the top, can be found in Table 4. In particular, policies such as Regulation 274/12 (a policy amending school-level hiring practices), Growing Success (a policy governing assessment, 
evaluation, and reporting in Ontario Schools) and Bill 212 (the jurisdictional Safe Schools Act) are having a large impact on principals' work.

Table 4. Provincial Policies that Influence Principals' Work.

\begin{tabular}{lccc}
\hline Policies & None & A Lot & N/A \\
\hline Regulation 274/12 - Hiring Practice & $0.7 \%$ & $79.6 \%$ & $1.0 \%$ \\
Growing Success & $0.1 \%$ & $77.4 \%$ & $0.3 \%$ \\
Safe School Act - Bill 212 & $0.2 \%$ & $69.1 \%$ & $0.4 \%$ \\
Bill 13 - Anti-Bullying & $0.3 \%$ & $65.7 \%$ & $0.3 \%$ \\
Bill 115 - Putting Students First Act & $1.0 \%$ & $65.4 \%$ & $0.1 \%$ \\
Full Day Kindergarten - Full Day Early Learning Statute Amendment Act & $11.6 \%$ & $50.5 \%$ & $18.6 \%$ \\
Information and Communication Technologies in Ed Management & $4.0 \%$ & $48.3 \%$ & $1.7 \%$ \\
Equity and Inclusive Education Strategy & $1.2 \%$ & $43.1 \%$ & $1.2 \%$ \\
Occupational Health and Safety Act & $3.3 \%$ & $34.8 \%$ & nil \\
Parents in Partnership: Parent Engagement Policy & $3.1 \%$ & $24.0 \%$ & $0.3 \%$ \\
Fluctuating Enrolment/School Closures & $27.3 \%$ & $23.4 \%$ & $10.9 \%$ \\
Aboriginal Education Strategy/FNMI Policy Framework & $29.8 \%$ & $6.8 \%$ & $4.3 \%$ \\
Urban Priority High Schools Initiative & $39.6 \%$ & $2.2 \%$ & $49.2 \%$ \\
\hline
\end{tabular}

Additional analysis also indicated that provincial policies are influencing principals' work. With a factor loading of 0.787 , provincial mandates were found to significantly affect the work of principals (See Table 5).

Table 5. Provincial Policies and Principals' Work.

\begin{tabular}{|c|c|c|c|c|}
\hline \multirow[t]{2}{*}{ Policies } & Safe Schools & $\begin{array}{c}\text { Enrolment \& } \\
\text { Technology }\end{array}$ & $\begin{array}{c}\text { Aboriginal \& Early } \\
\text { Childhood } \\
\text { Education } \\
\end{array}$ & $\begin{array}{l}\text { Hiring \& School } \\
\text { Improvement }\end{array}$ \\
\hline & Factor 1 & Factor 2 & Factor 3 & Factor 4 \\
\hline Aboriginal Education Strategy & 0.345 & -0.008 & -0.539 & -0.055 \\
\hline Bill 115 & 0.581 & -0.020 & -0.141 & 0.288 \\
\hline Bill 13 - Anti-Bullying & 0.768 & -0.027 & -0.044 & 0.020 \\
\hline Equity \& Inclusive Education Strategy & 0.654 & 0.063 & -0.033 & -0.115 \\
\hline Fluctuating Enrolment/School Closures & -0.017 & 0.603 & -0.408 & -0.140 \\
\hline Full Day Kindergarten & 0.144 & -0.035 & 0.763 & 0.007 \\
\hline Growing Success & $\underline{0.349}$ & $\underline{0.363}$ & 0.029 & 0.288 \\
\hline $\begin{array}{l}\text { Information \& Communication } \\
\text { Technologies }\end{array}$ & 0.053 & 0.758 & 0.060 & 0.096 \\
\hline Occupational Health \& Safety Act & 0.488 & 0.329 & 0.038 & -0.104 \\
\hline Parents in Partnership & 0.477 & 0.379 & 0.310 & -0.172 \\
\hline Regulation $274 / 12$ & 0.130 & 0.271 & 0.042 & 0.631 \\
\hline Safe Schools Act & 0.608 & 0.090 & 0.055 & 0.085 \\
\hline Urban Priority High Schools Initiative & 0.122 & 0.216 & -0.031 & -0.672 \\
\hline
\end{tabular}

Correlation analysis suggests that school principals who indicated that Regulation 274/12 had an impact on their work also showed that they spend more hours each week performing administrative management duties $(r=0.091)$, in areas such as budgeting, personnel, occupational health and safety, 
building maintenance, internal school management, and district school board office committees. For instance, one principal indicated: "Reg. 274 reduces the principal's ability to hire the best candidate, plus it has resulted in countless hours of work for Human Resources and Administrators." Another principal used the "Additional Comments" section of the survey to state: "the implementation of Reg. 274 has made this work extremely stressful and difficult, as I have not been able to choose the best person for my school and community." Regulation 274/12 seems particularly problematic for principals as it represents both a loss of autonomy and can have a negative impact on the teaching and learning occurring at the school-level.

The Growing Success policy is also having an impact on principals' work. Correlation analysis suggests that principals who rated high on the Growing Success tend to spend more time on both administrative management ( $r=0.058)$ and instructional leadership ( $r=0.064)$. The impact of Bill 212 (the jurisdictional safe schools act) also prompts principals to spend more time interacting with students and parents $(r=0.118)$. Although the correlation between the impact of these policies and principals' work is relatively small, it does imply that a single jurisdictional policy can increase principals' workload and shift the focus of their daily practice. Take Regulation 274/12 as an example; the comments by principals quoted above reveal that Regulation 274/12 represents a loss of autonomy, forces principals to hire perceived to be lower quality teaching staff, and diverts principals' attention away from instructional leadership [81]. These are all unintended consequences of a policy decision in which principals had little voice, and which may ultimately impact student learning. Percentages from principals' ratings regarding each provincial policy are displayed in Table 6. The results reveal principals' perceptions of each provincial policy and its impact on their work.

Table 6. Principals' Perceptions of the Impact of Provincial Policies on Their Work.

\begin{tabular}{lccccc}
\hline Variables & None & A Little & Some & A Lot & N/A \\
\hline Aboriginal Education Strategy & $29.8 \%$ & $39.7 \%$ & $18.8 \%$ & $6.8 \%$ & $4.3 \%$ \\
Bill 115 & $1.0 \%$ & $5.3 \%$ & $27.1 \%$ & $65.4 \%$ & $0.1 \%$ \\
Bill 13 - Anti-Bullying & $0.3 \%$ & $3.9 \%$ & $29.1 \%$ & $65.7 \%$ & $0.3 \%$ \\
Equity \& Inclusive Education Strategy & $1.2 \%$ & $10.5 \%$ & $44.3 \%$ & $43.1 \%$ & $1.2 \%$ \\
Fluctuating Enrolment/School Closures & $27.3 \%$ & $19.3 \%$ & $18.0 \%$ & $23.4 \%$ & $10.9 \%$ \\
Full Day Kindergarten & $11.6 \%$ & $5.2 \%$ & $13.2 \%$ & $50.5 \%$ & $18.6 \%$ \\
Growing Success & $0.1 \%$ & $2.2 \%$ & $19.2 \%$ & $77.4 \%$ & $0.3 \%$ \\
Information \& Communication & $4.0 \%$ & $11.5 \%$ & $34.0 \%$ & $48.3 \%$ & $1.7 \%$ \\
Technologies & $3.3 \%$ & $18.2 \%$ & $43.1 \%$ & $34.8 \%$ & nil \\
Occupational Health \& Safety Act & $3.1 \%$ & $25.1 \%$ & $46.5 \%$ & $24.0 \%$ & $0.3 \%$ \\
Parents in Partnership & $0.7 \%$ & $4.0 \%$ & $13.9 \%$ & $79.6 \%$ & $1.0 \%$ \\
Regulation 274/12 & $0.2 \%$ & $4.2 \%$ & $24.8 \%$ & $69.1 \%$ & $0.4 \%$ \\
Safe Schools Act & $39.6 \%$ & $4.9 \%$ & $2.4 \%$ & $2.2 \%$ & $49.2 \%$ \\
Urban Priority High Schools Initiative & & & & & \\
\hline
\end{tabular}

\subsection{External Influences and Partnerships}

In addition to policy impact from district school boards and the Ministry of Education, external organizations and partnerships also exert various influences on principals' work and their work 
environment. The ways in which external influences and partnerships moderate the work of school principals will be discussed in the following subsections.

\subsubsection{External Influences}

A factor analysis on the influence of external organizations on principals' work yields three factors: system organizations, school-community connection, and unions (see Table 7), ${ }^{3}$ these three factors account for $36.0 \%, 18.7 \%$, and $10.3 \%$ of the total variance $(65.0 \%)$, respectively.

Table 7. External Influences.

\begin{tabular}{lccc}
\hline Organizations & $\begin{array}{c}\text { System } \\
\text { Organizations }\end{array}$ & $\begin{array}{c}\text { School-Community } \\
\text { Connection }\end{array}$ & Unions \\
\cline { 2 - 4 } & Factor $\mathbf{1}$ & Factor 2 & Factor 3 \\
\hline District School Board & $\mathbf{0 . 5 6 5}$ & -0.397 & 0.227 \\
Ministry of Education & $\mathbf{0 . 6 5 9}$ & -0.299 & 0.367 \\
Ontario College of Teachers & $\mathbf{0 . 7 3 3}$ & 0.191 & 0.306 \\
Education Quality and Accountability Office & $\mathbf{0 . 7 1 5}$ & -0.073 & 0.275 \\
Literacy and Numeracy Secretariat (LNS) & $\mathbf{0 . 8 1 9}$ & 0.095 & -0.003 \\
Ministry of Labour & $\underline{0.554}$ & 0.049 & 0.521 \\
Teachers' Unions & 0.190 & 0.018 & $\mathbf{0 . 8 7 5}$ \\
Other Unions (e.g., CUPE) & 0.161 & 0.103 & $\mathbf{0 . 8 6 1}$ \\
Church/Faith Organization & 0.121 & $\mathbf{0 . 7 8 8}$ & 0.007 \\
Professional Associations (e.g., OPC) & $\mathbf{0 . 7 0 6}$ & 0.254 & 0.028 \\
Community Organizations (e.g., youth employment) & 0.159 & $\mathbf{0 . 8 6 2}$ & 0.075 \\
Other & -0.114 & $\mathbf{0 . 7 2 2}$ & 0.067 \\
\hline
\end{tabular}

Note: To enhance the interpretability of the factors, only variables with factor loads as follows were selected for inclusion in their respective factors: $>0.56$ (factor one), $>0.72$ (factor two) and $>0.86$ (factor three).

The results show that within the educational system, the Literacy and Numeracy Secretariat (LNS) has the greatest correlations with the system organizations. The LNS was established in 2004 to work with schools and district school boards across Ontario to build capacity and implement strategies to improve reading, writing, and math skills. Though the LNS was only mentioned by two principals in the "Additional Comments" section, these two principals indicated that the LNS provides a positive influence on principals' ability to be instructional leaders. For example, one principal stated: "Instructionally, I have found the conferences and monographs, etc. from LNS to be very helpful in my work as a curriculum leader." The LNS's influence on principals' work is also reflected in the policy titled Growing Success. Second to the LNS's influence on principals' work is that of the Ontario College of Teachers, the regulatory body for the teaching profession in Ontario.

Data analysis indicated that the Ministry of Labour has cross loadings on both system organizations and unions. In simpler terms, this finding implies that the Ministry of Labour, and in turn, occupational health and safety concerns, play a unique role in moderating principals' work by impacting the way principals interact with other system organizations and unions. The additional comments provided by

3 The item School Council is not included in the analysis as its influence originates within the school. 
principals who participated in the survey offer further evidence to highlight the power the Ministry of Labour wields over principals in Ontario's school system. For instance, typical comments related to this issue focused on how the attention principals pay to Ministry of Labour requirements takes time away from their roles as instructional leaders. One principal mentioned: "the amount of health and safety legislations and requirements that have nothing to do with education need to be reduced or given to other staff to oversee." Another principal stated: "Occupational Health and Safety, Ministry of Labour...coupled with the downloading of work have all contributed to a very fast paced job." These comments typify principals' views of how attention paid to occupational health and safety requirements takes time away from their roles as instructional leaders.

\subsubsection{Partnerships}

Principals in Ontario are expected to build relationships with community organizations and agencies connected to the students and communities the school serves. Approximately $75.8 \%$ of school principals in our sample were involved in between one and five partnerships at the school level. These findings indicate community organizations — such as faith-based organizations or youth employment agencies - have an influence on what principals do. In the "Additional Comments" section of the survey, principals indicated that school-community connections add more tasks and activities to their workload and diminish time available for high-priority tasks, such as those related to instruction. For example, one principal wrote that partnerships "add significantly to my workload and take away time that could be spent on instructional leadership and interacting with students and staff." Similarly, another principal stated that various partnerships "all significantly add to my workload, but all of these are very important." Notably, unions also play an important role in principals' work, particularly the provincial teachers' unions that does not include principals. This separation of principals and teachers into two different professional groups creates conflict, and was evident in recent labour strife between the provincial teachers' union and the Ontario government. Data analysis shows that approximately $31.7 \%$ of school principals feel that unions not at all or only somewhat respect them.

\subsection{Challenges and Possibilities}

Principals identified a number of challenges and possibilities associated with their work. Analysis revealed two main areas: work with teachers, and interactions with the school community and social environment. Some of these challenges can turn into possibilities; for example, with the development of high levels of trust between teachers and principals, some of their work can have a positive indirect effect on student achievement. Challenges related to student mental health and special education appear to be particularly complex in nature. Although our presentation of findings focuses mainly on challenges, they imply that such challenges can also be possibilities for principals if they are able to cope with and mitigate some of these challenges appropriately.

\subsubsection{Teachers}

Teachers present principals with some of the greatest challenges and possibilities found in their work. A factor analysis yielded the following four teacher-related factors eliciting an impact on 
principals and their work: principal-teacher interaction $(24.5 \%)$, teacher readiness and resistance $(18.0 \%)$, induction and turnover $(9.2 \%)$, and teacher professional development and growth (8.5\%). These factors account for $60.2 \%$ of the total variance explained, and are represented in Table 8 .

Table 8. Possibilities and Challenges: Teachers.

\begin{tabular}{ccccc}
\hline \multirow{2}{*}{ Items } & $\begin{array}{c}\text { Principal-Teacher } \\
\text { Interaction }\end{array}$ & Teacher Readiness & Induction \& & Teacher PD \\
& \& Resistance & Turnover & \& Growth \\
\cline { 2 - 5 } & Factor 1 & Factor 2 & Factor 3 & Factor 4 \\
\hline Discuss classroom issues with teachers & $\mathbf{0 . 7 8 1}$ & 0.016 & -0.023 & -0.112 \\
Open to hearing different perspectives & $\mathbf{0 . 7 6 1}$ & -0.042 & 0.009 & 0.095 \\
Let teachers know the expectations & $\mathbf{0 . 7 5 7}$ & 0.029 & 0.015 & -0.133 \\
Care about teachers' personal welfare & $\mathbf{0 . 6 0 8}$ & -0.231 & 0.051 & 0.179 \\
Lack of teacher knowledge and skills & 0.065 & $\mathbf{0 . 6 2 1}$ & 0.055 & 0.377 \\
Lack of time for teacher planning and PD & 0.059 & 0.122 & -0.002 & $\mathbf{0 . 8 5 1}$ \\
Lack of time to evaluate teachers & -0.095 & 0.164 & 0.311 & $\mathbf{0 . 6 9 3}$ \\
Difficult recruiting and hiring the right teachers & 0.025 & 0.238 & $\mathbf{0 . 7 2 0}$ & 0.151 \\
Teacher turnover & 0.048 & 0.012 & $\mathbf{0 . 8 0 7}$ & 0.065 \\
Difficulty terminating under-performing teachers & -0.062 & $\mathbf{0 . 5 3 2}$ & 0.464 & 0.043 \\
from the school & -0.150 & $\mathbf{0 . 7 9 2}$ & 0.146 & 0.123 \\
Teacher and staff apathy and resistance to change & -0.047 & $\mathbf{0 . 7 8 6}$ & 0.066 & 0.011 \\
Lack of trust between teachers and & & &
\end{tabular}

Challenges related to student mental health and special education appear to be particularly complex in nature. Being open to discussing classroom issues with teachers speaks to principals practicing the instructional leadership aspects of their role, while a willingness to hear different perspectives requires trust between principals and teachers. Both of the variables described above demonstrate possibilities available in contemporary work, particularly around building capacity: the benefits of building relationships with teachers and carving out time to be instructional leaders. However, these possibilities, which are built on positive relationships between principals and teachers, may be undermined by lack of trust between principals and teachers (factor loading $=0.786$ ), and resistance from teachers and staff (factor loading $=0.792$ ). These dual threats pose the greatest challenges to principals in their work. Further, principals also face challenges from teacher induction and turnover, which can change the composition in teacher quality, and eventually have a disruptive effect on school performance. A lack of time for teacher professional development (factor loading $=0.851$ ) and growth through teacher evaluation (factor loading $=0.693$ ) are additional teacher-related challenges that impact principals' work.

\subsubsection{School Community and Environment}

The myriad of challenges and possibilities encountered by principals in their work stems not only from teachers, but also from students, parents, the school community, and the larger political context (see Table 9). 
Table 9. Possibilities and Challenges: School Community and Environment.

\begin{tabular}{lccc}
\hline \multirow{2}{*}{ Items } & $\begin{array}{c}\text { School } \\
\text { Community }\end{array}$ & $\begin{array}{c}\text { Political } \\
\text { Environment }\end{array}$ & $\begin{array}{c}\text { Student Mental } \\
\text { Health \& Discipline }\end{array}$ \\
\cline { 2 - 4 } & Factor 1 & Factor 2 & Factor 3 \\
\hline Pressure to constantly adopt new programs & 0.071 & $\mathbf{0 . 7 8 3}$ & 0.097 \\
Provincial mandates (SE, ELL, etc.) & 0.031 & $\mathbf{0 . 7 8 7}$ & 0.171 \\
Lack of recognition for principals. & 0.152 & $\mathbf{0 . 7 0 9}$ & 0.024 \\
Lack of Special Education support/resources & -0.070 & $\underline{0.455}$ & $\underline{0.426}$ \\
Union Issues & 0.113 & $\mathbf{0 . 5 3 4}$ & 0.116 \\
Student discipline (bullying, aggressive behaviour, etc.) & 0.176 & 0.121 & $\mathbf{0 . 7 5 0}$ \\
Mental health issues among students/parents & 0.157 & 0.093 & $\mathbf{0 . 8 0 4}$ \\
Parents/guardians apathetic or irresponsible about their & 0.315 & 0.188 & $\mathbf{0 . 6 4 8}$ \\
children & & & \\
Lack of support from the school's community & $\mathbf{0 . 5 8 1}$ & 0.207 & 0.327 \\
Social problems in the school's community (poverty, & $\mathbf{0 . 7 4 4}$ & 0.043 & 0.347 \\
gangs, drugs, etc.) & & & -0.012 \\
Racial or ethnic tensions in the school's community & $\mathbf{0 . 7 9 6}$ & 0.108 & 0.136 \\
Negative stereotypes about this school's community & $\mathbf{0 . 8 1 2}$ & 0.036 & \\
\hline
\end{tabular}

After preparing the data for analysis using an orthogonal rotation of the variables, the 12 variables listed in the left-hand column of Table 9 clustered around the three factors at the top of the table. The three factors - school community $(32.6 \%)$, political environment (14.9\%), and student mental health and discipline (9.5\%) - account for $57.0 \%$ of the total variance explained. The analysis indicates that negative stereotypes about the school community (factor loading $=0.812$ ), racial or ethnic tensions at the school-level (factor loading $=0.796$ ), and social problems with the community (factor loading $=0.744$ ) are the most important elements associated with school community. Thus, the school community is having an impact on principals' work. Within the larger political context, pressure to constantly adopt new programs (factor loading $=0.783$ ), and a lack of recognition for principals (factor loading $=0.709$ ) also significantly affect principals' work. The cross loadings of "lack of special education support/resources" on factor 2 and 3 merit attention. It reveals that the political environment may affect the adequacy of support and resources that are needed for special education. It also suggests that issues concerning students' mental health and discipline can be aggravated or alleviated, dependent on the availability and adequacy of special education support and resources. Notably, mental health issues among students/parents (factor loading $=0.804$ ), and student discipline (factor loading $=0.750$ ) were identified as important factors that impact principals' work. For instance, in the "Additional Comments" section, principals mentioned: "the significant increase in initiatives from the Ministry and Board in the past five years has greatly impacted our ability to manage our schools." Another principal put it more bluntly, stating simply: "the pressures increase yearly." Principals also play a pivotal role in creating an environment that supports healthy choices and safe schools. A perceived lack of special education support/resources has cross loadings, or a large effect, on both the political environment and mental health and discipline. Perhaps this challenge is best explained by the following comment provided by one of the participating principals: 
...mental health of students and parents is a huge issue that impacts not only on my time, but my own emotions and wellbeing. I did not receive psychiatric training, but often feel as if I should have, given the amount of time I spend with adults with severe mental health issues.

This finding and the quote above demonstrate that special education and student mental health and discipline issues have a strong and interrelated influence on the work principals do on a daily basis.

\section{Discussion}

Scholars have put a great deal of effort into determining how school leadership influences student performance. Many of these efforts have focused on developing direct or indirect-effect models to determine promising leadership practices [7,20,24,25,84]. These inquires continue today [26], and are generating some promising practices for principals. Our findings, however, suggest that other factors not mentioned in the models, such as student mental health and discipline, political environment, system organizations, school-community connections, unions, and administrative management, to name a few, also need to be considered. Including these factors may help to extend the model to its antecedents and present a comprehensive picture of principals' work. They demonstrate that while principals do engage in many of the practices associated with instructional leadership, there are other factors that influence their work and compel them to engage in other practices as well. The increasing number of tasks required of principals complicates their work. More than this though, these tasks take time that principals often do not have. Many refer to this phenomenon as work intensification [85].

Current models imply that the groups of practices included within them are predominantly the only practices that principals engage in to fulfill their role. These models also give the impression that principals' work occurs in isolation. This is not the case. Our findings indicate a number of factors - some connected to instructional leadership and others not - interact to complicate principals' work. For example, multiple policies influence principals' work. Our data indicates that Regulation 274/12 and Bill 212 play a large role in what principals do in Ontario. These policies also influence principals' ability to engage in practices thought to directly/indirectly influence student outcomes. However, each policy does so in very different ways. For example, many Ontario principals believe that Regulation 274/12, which deals with hiring practices, influences their work because it is perceived to reduce principals decision-making when hiring teachers; it prevents them from hiring teachers they believe are the best fit for their school context. Ultimately, not having the best teachers will have an impact on student learning.

Our data also indicated that two other policies influence principals' focus on student learning: The Growing Success initiative and the Safe Schools Act. The Growing Success (2010) policy focuses on assessment, reporting processes for Ontario schools. This policy does support principals' work in relation to instructional leadership by providing a framework for assessment and including a formalized reporting process. However, some procedures required for data management can take away from other more relevant tasks that have a more direct impact on student outcomes. Bill 212, the Safe Schools Act, also influences principals' work. While this policy appropriately prompts principals to spend more time interacting with students and parents (which is also not necessarily a negative 
outcome), it also requires principals to devote considerably more time to paper work. This paper pushing, in turn, takes time away from engaging in instructional leadership practices.

Principals do not work in a vacuum; the work they do is always connected to a variety of practices and contexts. This was clear when we considered external influences such as system organizations, school-community connections and teacher unions. Since schools became part of school districts they have always had some connection to system organizations. However, it is the level of interaction with existing system organizations and the increase in interactions with additional system organizations that can also influence the work of school principals. For example, we have argued elsewhere that Ontario is experiencing a move to more centralized control of public education [78,86,87]. Our findings demonstrate that the Literacy and Numeracy Secretariat (LNS), for example, which is part of the Ministry of Education, has a significant impact on system organizations. In one sense, this is not surprising since the LNS is meant to support principals and schools in improving students outcomes and principals' instructional leadership endeavors. However, it is yet another initiative that demands more time from principals.

In addition to Ontario's traditional system organizations (district school boards and the ministry of education), other organizations impact schools such as the Educational Quality and Accountability Office (EQAO), the Ontario College of Teachers (OCT) and the Ministry of Labour. Of these organizations, our analysis determined that Ministry of Labour Policies, laws, and programs influence principals' work most significantly. As indicated in the findings, the Ministry of labour plays a unique role in moderating principals' work by influencing the way principals interact with other system organizations and teacher unions. The Ministry of Labour's mandate is not student success but to "advance safe, fair and harmonious workplace practices" [88] (n.p.). It does this by requiring that principals attend to occupational health and safety, employment rights and responsibilities, and labour relations. Ontario principals have a duty to abide by regulations that serve the employees in the school building rather than student learning. The repercussions of not fulfilling these duties can be severe for principals, and therefore, they tend to prioritize some of these tasks over other practices that may have a stronger connection to instructional leadership and student outcomes.

School-community connection and unions also influence principals' work. As mentioned earlier, Canada (and Ontario) caters to an increasingly diverse student population. Approximately, 76\% of school principals are involved in between one and five partnerships at the school level. Successful partnerships occur when there is a (a) clear goal established; (b) relationships built on trust; (c) way to communicate and share information; (d) process for decision-making; (e) ongoing connections; and (f) key stakeholders involved [89,90]. All of these necessary partnership components require principal involvement, and this involvement translates into additional formal and informal meetings, and additional communications and tasks specific to the partnership — all requiring additional time. While the outcome may indirectly influence student outcomes, there is only so much time that individuals have during a day, week or month, and so principals have to prioritize their work tasks. Our analysis of possibilities and challenges also indicates that even though principals are involved in multiple partnerships within their schools, they do so at times when there is lack of support from the school's community and in situations that are less than ideal, such as when school communities are facing social issues such as poverty, gangs and drug use, racial or ethnic tensions - all issues that add to the complexity of school principals' work. 
Ontario principals face other challenges that interfere with efforts to improve student learning. One of these involves union issues. Ontario has a highly unionized teacher workforce. Principals are not part of teacher unions. Our findings indicate tensions between unions (both teacher and other) and principals. Many principals indicated that they did not feel respected by the unions with which they dealt. As in any highly unionized work place, managers (principals in this case) have to figure out ways to work with others. Our findings suggest that teachers presented principals with some of the greatest challenges in their work. This is not surprising, given that the largest labour group principals work with are teachers. Instructional leadership involves working with teachers and so it is not a surprise that principal-teacher interaction ranked the highest of all four factors when it came to who presented principals with some of the greatest challenges.

Principals also have to deal increasingly with mental health issues. Recent studies have identified that student mental health is an emerging concern that needs to be addressed [1,64,81]. Issues connected to student mental health and well-being are also influencing principals' work. As our findings indicate, student mental health is often not a single factor, but is connected to student discipline and dealing with parents. When principals utilize their time to engage in activities such as finding community resources, securing referrals or mediating transitioning plans for students, they will not be engaged in instructional leadership tasks, activities or behaviors.

Our analysis demonstrates how various factors and antecedents interact to complicate principals' work. Further exploration of direct/indirect models need to take into consideration factors that moderate principals' work. Many parts of our analysis are not surprising to both practitioners and researchers; the more important question is to ask why? What is happening? Our data indicate that principals are experiencing two things: loss of autonomy and work intensification. Because of a more centralized schooling system and subsequent changes in how work is to be carried out, principals are becoming more like atypical middle managers with reduced power and decision-making. Evidence to support this includes a reduced voice in hiring teachers, increased influences outside the school site, and extensive policy driven action and practices, to name a few.

Principals are experiencing work intensification. In addition to some of the factors reported here that influence principals' work, we know that principals are working long hours. It is also intensifying at a rapid pace [64,81]. Ontario principals spend approximately $59 \mathrm{~h} /$ week at work [81], $14 \mathrm{~h} /$ week more than Canadian occupational managers [91] and public sector professional executives, who work on average $51 \mathrm{~h} /$ week [83]. Yet, $87 \%$ of principals indicated they never seem to have enough time to do their work, while more than $72 \%$ of participating principals felt pressured to work long hours and only $38 \%$ felt they had the resources necessary to do their job properly. The trend toward work intensification is not isolated to Canada. In a 2013 survey by the National Association for Head Teachers in the UK, $78.9 \%$ of school leaders reported that their workload had increased compared to a year ago. Also, the 2013 Teaching and Learning International Survey shows that participating countries consistently ranked high workload, inadequate resources, and government regulations as the top three barriers to principal effectiveness. Not only is principals' work intense, requiring multiple task and activities, it is complex as many of these factors are interconnected. 


\section{Conclusions}

Many studies of educational leadership focus on how educational leadership affects student achievement and school performance, and whether such an effect is direct [21] or indirect [24,25]. A common understanding among scholars is that educational leadership plays a pivotal role in improving student achievement. Leadership approaches, such as transformational leadership [92] and instructional leadership [93], are often identified as particularly important. Given the increasing complexity of principals' work and increasingly diverse student populations in schools, many factors interact to have an impact on school leaders and their work. In addition to looking into how leadership affects student achievement and school performance, it is also important to investigate what factors influence principals' choices of leadership approaches and practices. We argue that principals' choices of leadership approaches and practices are subject to factors that exist within and beyond schools. Such factors moderate the way that principals carry out their work and limit their choices in exercising their professional autonomy. Our study provides empirical evidence on factors that should be taken into account in leadership roles and practices. Sensitivity to these factors will help to enhance the effects of school principals' work, which ideally will lead to better student achievement and school performance.

\section{Acknowledgments}

The Ontario Principals' Council funded this study. None of the funds received were to cover the costs to publish in open access journals.

\section{Author Contributions}

Katina Pollock, Fei Wang, and Cameron Hauseman conceived, designed and performed the study; Katina Pollock, Fei Wang, and Cameron Hauseman analyzed the data; Katina Pollock contributed reagents/materials/analysis tools; Katina Pollock, Fei Wang, and Cameron Hauseman wrote the paper.

\section{Conflicts of Interest}

The authors declare no conflict of interest. The funding sponsors had no role in the design of the study; in the collection, analyses, or interpretation of data; in the writing of the manuscript, and in the decision to publish the results.

\section{References}

1. Canadian Association of Principals. The future of the principalship in Canada: A national research study. Available online: http:/www.teachers.ab.ca/SiteCollectionDocuments/ATA/Publications/ Research/The\%20Future\%20of\%20the\%20Principalship\%20in\%20Canada.pdf (accessed on 15 July 2014).

2. Horng, E.L.; Klasik, D.; Loeb, S. Principal's time use and school effectiveness. Am. J. Educ. 2010, 116, 491-523.

3. Kmetz, J.T.; Willower, D.J. Elementary school principals' work behavior. Educ. Adm. Q. 1982, $18,62-78$. 
4. Lee, M.; Hallinger, P. National contexts influencing principals' time use and allocation: Economic development, societal culture and educational system. Sch. Eff. Sch. Improv. 2012, 23, 461-482.

5. Martin, W.J.; Willower, D.J. The managerial behavior of high school principals. Educ. Adm. $Q$. 1981, 17, 69-90.

6. Martinko, M.J.; Gardner, W.L. Structured observation of managerial work: A replication and synthesis. J. Manag. Stud. 1990, 27, 329-357.

7. Hendriks, M.; Sheerens, J. School leadership effects revisited: A review of empirical studies guided by indirect-effects models. Sch. Leadersh. Manag. 2013, 33, 373-395.

8. Lomos, C.; Hofman, R.H.; Bosker, R.J. Professional communities and student achievement-A meta-analysis. Sch. Eff. Sch. Improv. 2011, 22, 121-148.

9. Louis, K.; Dretzke, B.; Wahlstrom, K. How does leadership affect student achievement: Results from a national US survey. Sch. Eff. Sch. Improv. 2010, 21, 315-336.

10. Robinson, V.; Lloyd, C.; Rowe, K. The impact of leadership on student outcomes: An analysis of the differential effects of leadership types. Educ. Adm. Q. 2008, 44, 635-674.

11. Harris, D.N.; Rutledge, S.A.; Ingle, W.K.; Thompson, C.C. Mix and match: What principals look for when hiring teachers and implications for teacher quality policies. Educ. Financ. Policy 2010, $5,228-246$.

12. Jacob, B.A.; Lefgren, L. Principals as agents: Subjective performance measurement in education. 2005 Faculty Research Working Paper Series RWP05-040. Available online: http://www. nber.org/papers/w11463.pdf (accessed on 12 September 2014).

13. Leithwood, K.A.; Riehl, C. What we know about successful school leadership. A report by Division A of AERA. 2003 National College for School Leadership. Available online: http://dcbsimpson.com/randd-leithwood-successful-leadership.pdf (accessed on 29 September 2014).

14. Leithwood, K. The Ontario Leadership Framework 2012: A discussion of research foundations. Available online: http://iel.immix.ca/storage/6/1345688978/Final_Research_Report_-_EN.pdf (accessed on 12 September 2013).

15. Bickmore, K. Policies and programming for safer schools: Are anti-bullying approaches impeding education for peacebuilding? Educ. Policy 2011, 24, 648-687.

16. Brewer, D. Principals and student outcomes: Evidence from U.S. high schools. Econ. Educ. Rev. 1993, 12, 281-292.

17. Eberts, R.W.; Stone, J.A. Student achievement in public schools: Do principals make a difference? Econ. Educ. Rev. 1988, 7, 291-299.

18. Knapp, M.S.; Copland, M.A.; Plecki, M.L.; Portin, B.S. Leading, learning, and leadership support. Available online: https://depts.washington.edu/ctpmail/PDFs/Synthesis-Oct16.pdf (accessed on 11 April 2014).

19. Leithwood, K.; Seashore Louis, K.; Anderson, S.; Wahlstrom, K. How leadership influences student learning: A review of research for the Learning from Leadership Project. Available online: http://www.wallacefoundation.org/knowledge-center/school-leadership/key-research/Documents/ How-Leadership-influences-Student-Learning.pdf (accessed on 8 May 2013). 
20. Hallinger, P.; Wang, W.; Chen, C. Assessing the measurement properties of the principal instructional management rating scale: A meta-analysis of reliability studies. Educ. Adm. Q. 2013, 49, 272-309.

21. Witziers, B.; Bosker, R.J.; Kruger, M.L. Educational leadership and student achievement: The elusive search for association. Educ. Adm. Q. 2003, 39, 398-425.

22. Day, C.; Sammons, P.; Hopkins, D; Harris, A.; Leithwood, K; Gu, Q.; Brown, E.; Ahtaridou, E.; Kington, A. The Impact of School Leadership on Pupil Outcomes; Final Report; The National College for School Leadership: Nottingham, UK, 2009.

23. Leithwood, K.; Jantzi, D. Linking Leadership to Student Learning: The Contributions of Leader Efficacy. Educ. Adm. Q. 2008, 44, 496-528.

24. Mulford, B. School leaders: Changing roles and impact on teacher and school effectiveness. Available online: http://www.oecd.org/edu/school/2635399.pdf (accessed on 20 July 2013).

25. Silins, H.; Mulford, B. Schools as learning organisations-Effects on teacher leadership and student outcomes. Sch. Eff. Sch. Improv. 2004, 15, 443-466.

26. Leithwood, K.; Patten, S.; Jantzi, D. Testing a conception of how school leadership influences student learning. Educ. Adm. Q. 2010, 46, 671-706.

27. Merriam-Webster.com. Work. Available online: http://www.merriam-webster.com/dictionary/work (accessed on 15 November 2013).

28. Drago, R. Striking a Balance: Work, Family, Life; Dollars and Sense: Boston, MA, USA, 2007.

29. Ryan, J. The New Institutionalism in a Postmodern World: De-differentiation and the Study of Institutions. In The Politics of Education and the New Institutionalism: Reinventing the American School; Crowson, R., Boyd, W.L., Mawhinney, H., Eds.; Falmer: London, UK, 1996; pp. 189-202.

30. Applebaum, P.D. The Concept of Work: Ancient, Medieval and Modern; SUNY Press: Albany, NY, USA, 1992.

31. Gamst, F.C. Meanings of Work: Considerations for the 21st Century; SUNY Press: New York, NY, USA, 1995.

32. Leithwood, K.; Beatty, B. Leading with Teacher Emotions in Mind; Corwin: Thousand Oaks, CA, USA, 2007.

33. Bakker, A.B.; van Emmerik, H.; Euwema, M.C. Crossover of burnout and engagement in work teams. Work Occup. 2006, 33, 464-489.

34. Mauno, S.; Kinnunen, U.; Ruokolainen, M. Exploring work- and organization-based resources as moderators between work-family conflict, well-being, and job attitudes. Work Stress 2006, 20, 210-233.

35. Hallinger, P. A review of three decades of doctoral studies using the Principal Instructional Management Rating Scale: A lens on methodological progress in educational leadership. Educ. Adm. Q. 2011, 47, 271-306.

36. Education Act, Revised Statues of Ontario 1990, c.E.2.

37. The Institute for Education Leadership. Putting Ontario's leadership framework into action: A guide for school and system leaders. Available online: http://www.educationleadership-ontario.ca/files/ FrameworkAction.pdf (accessed on 15 November 2013). 
38. Pollock, K.; Hauseman, D.C. School Leadership in Canada. In Cross Country Histories of School Leadership Research: Focus and Findings; Ärlestig, H., Day, C., Johansson, O., Eds.; Springer: Dordrecht, The Netherlands, 2015; pp. 202-232.

39. OECD Library. Education at a Glance 2013: OECD Indicators. Available online: http://dx.doi.org/10.1787/eag-2013-en (accessed on 29 April 2014).

40. Horng, E.L.; Loeb, S. New thinking about instructional leadership. Phi Delta Kappan 2010, 92, 66.

41. Norton, M.S. The Principal as Human Resources Leader: A Guide to Exemplary Practices for Personnel Administration; Routledge: New York, NY, USA, 2015.

42. Preiss, B. State school principals face impossible choices on building maintenance. The Victoria Age. Available online: http://www.theage.com.au/victoria/state-school-principals-face-impossiblechoices-on-building-maintenance-20141015-116k7x.html (accessed on 29 September 2014).

43. Chan, T.C. Beyond the status quo: Creating a school maintenance program. Princ. Leadersh. 2000, 3, 64-67.

44. Riley, P. Australian principal occupational health, safety and wellbeing survey: 2011-2014 data. Available online: http://www.principalhealth.org/2011-14\%20Report_FINAL.pdf (accessed on 10 December 2014).

45. Kemeny, A. Déterminés à réussir - un portrait des bourreaux de travail au Canada. Stat. Can. 2002, 64, 2-8.

46. Shields, M. Les longues heures de travail et la santé. Stat. Can. 2000, 12, 53-62.

47. Vezina, M. Évolutions des Conditions de Travail et Santé Psychique; Octares: Toulouse, France, 2002.

48. Hands, C. Why collaborate? The differing reasons for secondary school educators' establishment of school-community partnerships. Sch. Eff. Sch. Improv. 2010, 21, 189-207.

49. Clandfield, D. The school as a community hub: A public alternative to the neoliberal threat to Ontario schools. Our Sch. Our Selves 2010, 19, 5-74.

50. Koyama, J. Principals, power, and policy: Enacting "supplemental educational services". Anthropol. Educ. Q. 2011, 42, 20-36.

51. Auerbach, S. Beyond coffee with the principal: Toward leadership for authentic school-family partnerships. J. Sch. Leadersh. 2010, 20, 728-757.

52. Rogers, J.; Freeton, R.; Terriquez, V. Enlisting collective help: Urban principals' encouragement of parent participation in school decision-making. In School Leadership for Authentic Family and Community Partnerships: Research Perspectives for Transforming Practice; Auerbach, S., Ed.; Routledge: New York, NY, USA; pp. 55-77.

53. Best, A.; Holmes, B. Systems thinking, knowledge and action: Towards better models and methods. Evid. Policy 2010, 6, 145-159.

54. Pollock, K. Policy as outcome: Inequities generated from unintended policy outcomes. Can. Int. Educ. J. 2006, 35, 35-47.

55. Ontario College of Teachers. Ontario College of Teachers Principals Qualification Program 2009. Available online: https://www.oct.ca/-/media/PDF/Principals\%20Qualification\%20Program\% 202009/principals_qualification_program_e.pdf (accessed on 22 September 2014).

56. Blakesley, S. Juggling educational ends: Non-Indigenous Yukon principals and the policy challenges that they face. Int. J. Educ. Policy Leadersh. 2012, 7, 1-14. 
57. Fink, D. The Succession Challenge Building and Sustaining Leadership Capacity through Succession Management; SAGE Publications: New York, NY, USA, 2010.

58. Smith, A.J. Generative leadership: Profile of effective 21st century secondary school principals (Order No. NR49647). Available from ProQuest Dissertations \& Theses Global. (304833957). Available online: http://search.proquest.com/docview/304833957?accountid=12792_(accessed on 27 January 2015).

59. Pinto, L.E. Fear and loathing in neoliberalism: School Administrator responses to policy layers. J. Educ. Adm. Hist. 2015, 46, 140-154.

60. Hauseman, D.C.; Pollock, K. Principals' work with ICT: A doubled-edged sword. Presented at the University Council for Educational Administration (UCEA) Conference, Washington, DC, USA, 22 November 2014.

61. Fullan, M. The Principal: Three Keys to Maximizing Impact; Jossey-Bass: San Francisco, CA, USA, 2014.

62. Sheninger, E. Digital Leadership: Changing Paradigms for Changing Times; Corwin: Thousand Oaks, CA, USA, 2014.

63. Brockmeier, L.T.; Sermon, J.M.; Hope, W.C. Principals' relationship with computer technology. NAASP Bull. 2005, 89, 45-57.

64. Leithwood, K.; Azah, V.N. Elementary Principals' and Vice-Principals' Workload Studies: Final Report. Available online: https://www.cpco.on.ca/files/4414/1598/3416/Full_Elementary_Report_ October_7_2014_Final.pdf (accessed on 22 January 2015).

65. Ryan, J. Administrative approaches to diversity: Imposing and sharing meaning. In International Handbook on Leadership for Learning; MacBeath, J., Townsend, T., Eds.; Springer: Dordrecht, The Netherlands, 2011; pp. 1125-1142.

66. Kelley, N.; Trebilcock, M.J. The Making of the Mosaic: A History of Canadian Immigration Policy; University of Toronto Press: Toronto, ON, Canada, 2010.

67. Statistics Canada. Immigration and Ethnocultural Diversity in Canada. Available online: http://www12.statcan.gc.ca/nhs-enm/2011/as-sa/99-010-x/99-010-x2011001-eng.pdf (accessed on 22 January 2015).

68. Alberta Teachers' Association (ATA). Leadership for Learning: The Experience of Administrators in Alberta Schools. Available online: www.teachers.ab.ca/SiteCollectionDocuments/ATA/Publications/ Research/PD-86-14\%20Leadership\%20for\%20Learning.pdf (accessed on 22 September 2014).

69. Flessa, J.; Gallagher-Mackay, K.; Parker, D.C. "Good, Steady Progress": Success Stories from Ontario Elementary Schools in Challenging Circumstances. Can. J. Educ. Adm. Policy 2010, 101, 1-38.

70. Whyte, W. The Organization Man; Simon \& Shuster: New York, NY, USA, 1956.

71. Elmore, R. Accountable leadership. Educ. Forum 2005, 69, 134-142.

72. Darling-Hammond, L. Accountability for professional practice. Teach. College Record 1989, 91, 59-80.

73. Firestone, W.A.; Shipps, D. How do leaders interpret conflicting accountabilities to improve student learning? In A New Agenda for Research in Educational Leadership; Firestone, W.A., Riehl, C., Eds.; Teachers College Press: New York, NY, USA, 2007; pp. 81-100. 
74. Pollock, K.; Winton, S. Juggling multiple accountability systems: How three principals manage these tensions. Educ. Assess. Eval. Account. 2015, accepted for publication.

75. Stone, B.; Jabbra, J.G.; Dwivedi, O.P. (Eds.) Public Service Accountability: A Comparative Perspective; Kumarian Press: Hartford, CT, USA, 1989.

76. Ben Jaafar, S.; Earl, L. Comparing performance-based accountability models: A Canadian example. Can. J. Educ. 2008, 31, 697-728.

77. Wallace, J. Facing "reality": Including the emotional in school leadership programmes. J. Educ. Adm. 2010, 48, 595-610.

78. Murakami, E.; Pollock, K. Editorial introduction. Can. Int. Educ. 2014, 43, Article 1.

79. Murakami, E.; Torenson, M.; Pollock, K. Expectations for the preparation of school principals in three jurisdictions: Sweden, Ontario, and Texas. Can. Int. Educ. 2014, 43, Article 7.

80. Creswell, J.W. Research Design: Qualitative, Quantitative, and Mixed Method Approaches, 3rd ed.; Sage Publications: Los Angeles, CA, USA, 2009.

81. Pollock, K.; Wang, F.; Hauseman, D.C. The changing nature of principals' work: Final report. Available online: http://www.edu.uwo.ca/faculty_profiles/cpels/pollock_katina/OPC-PrincipalsWork-Report.pdf (accessed on 22 January 2015).

82. Leithwood, K.; Anderson, S.; Mascall, B.; Strauss, T. School Leaders' Influences on Student Learning: The Four Paths. In The Principles of Educational Leadership and Management; Bush, T., Bell, L., Middlewood, D., Eds.; Sage: London, UK, 2010; pp. 13-30.

83. Association of Professional Executives of the Public Service of Canada. APEX 2012 Executive Work and Health Survey. Available online: http:/www.apex.gc.ca/uploads/key\%20priorities/ health/2012\%20health\%20survey\%20results\%20-\%20eng.pdf (accessed on 8 July 2014).

84. Bossert, S.T.; Dwyer, D.C.; Rowan, B.; Lee, G.V. The instructional management role of the principal. Educ. Adm. Q. 1982, 18, 34-64.

85. Allan, C.; O’Donnell, M.; Peetz, D. More tasks, less secure, working harder: Three dimensions of labour utilisation. J. Ind. Relat. 1999. 41, 519-535.

86. Galway, G.; Sheppard, B.; Weins, J.; Brown, J. The impact of centralization on local school governance in Canada. Can. J. Educ. Adm. Policy 2013, 145, 1-34.

87. Sattler, P. Education governance reform in Ontario: Neoliberalism in context. Can. J. Educ. Adm. Policy 2012, 128, 1-28.

88. Ontario Ministry of Labour. About the Ministry. Available online: http://www.labour. gov.on.ca/english/about/index.php (accessed on 22 September 2014).

89. Finn-Stevenson, M. Family, school, and community partnerships: Practical strategies for afterschool programs. New Dir. Youth Dev. 2014, 2014, 89-103.

90. Thomas, M.; Rowe, F.; Harris, N. Understanding the factors that characterise school-community partnerships. Health Educ. 2010, 110, 427-444.

91. Statistics Canada. Table 282-0026: Labour force survey estimates (LFS), by actual hours worked, class of worker, National Occupational Classification for Statistics (NOC-S) and sex. Available online: http://www5.statcan.gc.ca/cansim/a05?lang=eng\&id=2820026\&pattern= 2820026\&searchTypeByValue=1\&p2=35 (accessed on 12 April 2014). 
92. Leithwood, K.; Jantzi, D. The effects of transformational leadership on organizational conditions and student engagement with school. J. Educ. Adm. 2000, 38, 112-129.

93. Marks, H.M.; Printy, S.M. Principals leadership and school performance: An integration of transformational and instructional leadership. Educ. Adm. Q. 2003, 39, 370-397.

(C) 2015 by the authors; licensee MDPI, Basel, Switzerland. This article is an open access article distributed under the terms and conditions of the Creative Commons Attribution license (http://creativecommons.org/licenses/by/4.0/). 